\title{
Factors Affecting the Choice of School and Students' Level of Interest towards the Maritime Program
}

\author{
Carlos L. Aguado ${ }^{1}$, Jake M. Laguador ${ }^{2} \&$ Joseph Cezar L. Deligero ${ }^{3}$ \\ ${ }^{1}$ Lyceum International Maritime Academy, Lyceum of the Philippines University, Batangas City, Philippines \\ ${ }^{2}$ Research and Statistics Center, Lyceum of the Philippines University, Batangas City, Philippines \\ ${ }^{3}$ Strategic Communications and Alumni Affairs, Lyceum of the Philippines University, Batangas City, \\ Philippines
}

Correspondence: Jake M. Laguador, Research and Statistics Center, Lyceum of the Philippines University, Batangas City, 4200, Philippines. Tel: 63-917-533-5261. E-mail: jakelaguador@gmail.com

Received: April 27, 2015 Accepted: June 10, 2015 Online Published: July 6, 2015

doi:10.5539/ass.v11n21p231 URL: http://dx.doi.org/10.5539/ass.v11n21p231

\begin{abstract}
Several factors may be considered in selecting school and degree program like quality education, the people from the environment, personal choice; and accessibility of the school from students' residences. This study utilized a descriptive type of research method with Freshman Maritime students as respondents. Findings revealed that it is the personal choice of the students to enroll in maritime program in Lyceum of the Philippines University-Batangas (LPU-B) with the support primarily from their parents wherein quality education through being known as home of board topnotchers and its standards are considered big factor for their decision. They also believed that finishing maritime education would bring them in employment abroad which is basically the nature of duties and responsibilities of seafarers. High interest towards the degree program is also manifested among the maritime students. Maritime students graduated from public schools have significantly higher chance of being influenced by people in choosing the school and degree program and they also have significantly higher degree of interest towards the maritime program compared to those graduated from private schools.
\end{abstract}

Keywords: quality education, interest, maritime education, LPU, Filipino

\section{Introduction}

Graduating students from secondary schools may not have solid decision on where to go in college and what degree program they may possibly take. They are planning to enter college without clear idea of what career to pursue for their future (Ramirez \& Dizon, 2014). They may sometimes consider the people and the information they received within their environment. There are several factors that may affect the decision of students and parents, where it can be a good source of insight for private higher education institutions to offer quality services that will suit to the needs, expectations and demands of the community. Academic institutions sought to observe the requirements of the customers, prospective students and other clients like industry partners when preparing an educational program (Hrnciar \& Madzík, 2013). Degree programs and other student services are being developed to promote the image of the university (Nadelson, Semmelroth, Martinez, Featherstone, Fuhriman, \& Sell, 2013).

With the curricular offerings of private colleges and universities which are almost identical programs makes diversification very difficult (Vaz \& Mansori, 2013). Therefore, the competitive edge, uniqueness and quality must be established in educational marketing through image building while helping and guiding the parents towards the achievement of their desire for the success of their children.

The decision on good career choice and school sometimes depend on how the way students perceive the world and their future. Some of them may not have enough knowledge and consciousness about how they should process information from personal, social, economical, political, spiritual and environmental aspects of putting into context and realization of having a successful profession. Pafili and Mylonakis (2011) emphasized that in coming up with the right decision of what profession to take, students can properly utilize their skills and knowledge to gain proper experience who could contribute to the development and welfare of the society but Koni, Zainal, and Ibrahim (2012) noted that some studies show that not all students who enter a university have the intention to obtain the degree. 
This study is more on preventive rather than a corrective action on the problems or consequences that may occur when the implementation of K-12 in the Philippines will reach in 2016 wherein no first year students will enroll in college. Deeper understanding on how customers make their choices and who make the choices are essential considerations in image building, marketing and advertising. The faculty members, students and marketing staff of the university assist the graduating students from various secondary schools within its vicinity and along the neighboring towns in the region to think of the appropriate college degree program that will be suitable to the needs of their respective communities or match to their line of interest. They provide possible options and the opportunities to be well oriented and informed of the program offerings that would make them excel and successful. Hirschi and Läge (2007) noted that the educational career starts officially in Grade 8 among students in Switzerland and it seems to assume that they enter this process with the same conditions and mostly uninformed of existing choices. This time, they will be orienting junior high school students to enter in the senior high school with properly selected academic track: Accountancy, Business and Management (ABM) Strand; Humanities and Social Sciences Strand (HUMSS); Science, Technology, Engineering and Mathematics (STEM) Strand while other colleges and universities will be offering other tracks based on the approval of the Department of Education.

The choice of career of the students is being influenced by some factors from the social environment, mainly the parents as immediate family who plays an active role in choosing the right education for their children (Pafili \& Mylonakis, 2011). As a sign of respect for the parents and culture of the Filipinos, parents or the elderly are being consulted first by their children because primarily they will be the one to provide the financial support to enter in college (Laguador, 2013).

This present study explores the last phase of the Career Decision-Making Process Model of Hirschi and Läge (2007) which is the after actual decision-making which aims to determine, whether if the maritime program is definitely the college degree that the students under study really aspire to pursue, either personal choice or with consent and approval from other people. This is also relevant to the social cognitive theory of Bandura (1986) which explores the maturity and development of interest and career and how these things turned into action.

It is important for the institution to identify the willingness of the students to pursue the program where interest can be used as good indicator of career choice (Hirschi \& Läge, 2008), so that if problems might occur in their academic performance related to negative attitude, the result of this study might be useful to explain the situation.

Part of the study is the issue of the type of high school where the Maritime students graduated either from public or private secondary schools. Estevan (2014) emphasized that in Brazil, although there is an improvement in the quality of public school which may also increase enrollment; there are some students who prefer private education now choose public schools. In the Philippines, based on personal observation that most parents transferred their children from private to public schools due to the global economic recession which parents working abroad become unemployed or they are receiving lesser amount of salary compared to their normal compensation. Some political challenges that the country faced for the past and present administrations make the parents financially affected. This study also explores the differences on how these students from private and public schools really value their college degree to become future seafarers to seek greener pastures from other countries.

Majority of the parents who can afford to educate their children in private schools are those capable to sustain in paying high tuition and other miscellaneous fees, projects, assignments and co-curricular activities. The nature of student life in public school is different from private due to the different levels of economic status which may somehow influence the attitude and behavior of the students towards on how they look at the environment based on their social orientation within their sphere. Student development can be equated from the kind of activities and quality of life that a school can provide wherein the success of every outcome still depends on how the students appreciate and apply the learning from various experiences.

It is a good insight for the academic institution to determine the reasons of the students for choosing them as a training ground for their college degree. This serves as initial information to strengthen the services of the university towards the attainment of its objectives and fulfillment of the expectations of its clients, stakeholders and the community, therefore, this study was conducted.

\section{Objectives of the Study}

The study aims to investigate the factors affecting the choice of school and degree program of the Freshman Year Maritime Students. It specifically aimed to identify the persons who could primarily influence the choice of the respondents to decide what degree program to take and enroll in LPU; to determine the reasons of the 
respondents for the selection of school based on quality education, influence of people, personal preference; and accessibility and proximity; to determine the level of their interest towards maritime program; and test the difference between students' perception from private and public high school on the factors affecting their choice of school and level of interest towards the maritime program.

Ho: There is no significant difference on the factors affecting choice of school and level of interest on the maritime program between students who graduated from the private and public schools.

\section{Research Methodology}

\subsection{Research Design}

Descriptive-survey research method was employed to analyze and interpret the result of the study. It is considered appropriate to describe the nature of the phenomenon based on the perceived condition and status of some simple observable situations (Costales \& Zulueta, 2003).

\subsection{Participants}

Out of one thousand Marine Engineering and Marine Transportation freshman students of LPU-B, 30 percent or 300 regular full time students were randomly selected to answer the survey. Systematic random sampling was used in identifying the respondents. Transferees from other universities and shifters from other degree programs were not included in the study because they have already experienced the college life; they are already adjusted and the level of their interest might be already different from those freshmen. Part-time students or those working students were also excluded due to different level of their responsibilities and priorities in life not only as student but also an employee. From the randomly selected participants, 181 of 60.3 percent of them were graduated private high schools against 119 or 39.7 percent from public schools. Records of the students were taken from Registrar's office of the university. Since maritime program is dominated by males which are almost 98 percent, female students were also excluded as respondent of the study. Those students who refused to participate in the study were replaced by respondents who were preliminary drawn from the list in case of non-participation of selected students were identified based on their willingness to participate in the study and they are from the same age bracket of 16 to 18 years old and with guardians, brothers or sisters living with them.

\subsection{Instrument}

The survey questionnaire was employed in identifying the persons who could primarily influence the choice of the respondents to decide what degree program to take in college and to enroll in LPU which was adapted from the study of Laguador (2013) in determining the career choice of engineering freshmen. The instrument was modified based on the specific objectives of the study. Another part of the instrument is to determine the reasons of the maritime students for the selection of school based on quality education, influence of people, personal choice as well as accessibility and proximity of the school. The instrument was content validated by the Director of Counseling and Testing Center of the University, Educational Psychologist and the Research Director. It was pre-tested to the Engineering students from the same institution since this degree program is also dominated by male students from the same year level and age bracket. The instrument obtained a computed Cronbach alpha of 0.78 which is already considered good or reliable to use.

\subsection{Procedure}

The instrument was personally administered by the researchers and staff of the Maritime Academy before the end of 1st semester SY 2014-2015. They were asked to participate in the survey with an informed consent. Participants were informed regarding the objective of the study and the confidentiality of the result which will be utilized solely in the purpose of this research. The ethical standards on conducting research with human as respondents had met by this study. They have the freedom to decline their participation in the study if they don't feel like answering the instrument due to busy schedule and other personal reasons.

\subsection{Data Analysis}

Results of the data gathered were analyzed and interpreted using weighted mean and ranking while independent sample t-test was employed to test the difference between maritime students from private and public schools in terms of the factors affecting their choice of school and level of interest towards maritime program.

The given scale was utilized to discuss the result of the data gathered.

\begin{tabular}{lllr} 
Weight & \multicolumn{1}{c}{ Range } & \multicolumn{2}{c}{ Verbal Interpretation (VI) } \\
4 & $3.50-4.00$ & Very Much (VM) & Strongly Agree (SA) \\
3 & $2.50-3.49$ & Much (M) & Agree (A)
\end{tabular}




$$
\begin{array}{lllr}
2 & 1.50-2.49 & \text { Little (L) } \quad \text { Disagree (D) } \\
1 & 1.00-1.49 & \text { Not at all (NA) } & \text { Strongly Disagree (SD) }
\end{array}
$$

\section{Results and Discussion}

Table 1 shows the degree of persons' influenced on the Maritime Students' Choice of Degree Program and School. It is the Maritime students' own choice to take Maritime Program and enroll in LPU-Batangas as manifested by the computed weighted mean scores of 3.53 and 3.52 , respectively.

Table 1. Persons who influenced the maritime students' choice of degree program and school

\begin{tabular}{ccccccc}
\hline Persons who influenced them & Degree Program & VI & Rank & School & VI & Rank \\
\hline 1. Father & 3.28 & $\mathrm{M}$ & 3 & 3.41 & $\mathrm{M}$ & 2 \\
2. Mother & 3.46 & $\mathrm{M}$ & 2 & 3.32 & $\mathrm{M}$ & 3 \\
3. Brother/Sister & 3.25 & $\mathrm{M}$ & 4 & 3.03 & $\mathrm{M}$ & 6 \\
4. Relatives & 3.15 & $\mathrm{~L}$ & 7 & 2.32 & $\mathrm{~L}$ & 7 \\
5. Friends & 3.21 & $\mathrm{M}$ & 5 & 3.09 & $\mathrm{M}$ & 5 \\
6. Teacher & 3.16 & $\mathrm{M}$ & 6 & 3.25 & $\mathrm{M}$ & 4 \\
7. Own Choice & 3.53 & $\mathrm{VM}$ & 1 & 3.52 & $\mathrm{VM}$ & 1 \\
\hline
\end{tabular}

Meanwhile, parents have much influenced mostly mothers in taking the degree and fathers in choosing the school followed by teachers and friends. Children are still being asked by their parents where they wanted to pursue their college degree but parents are considered the most influential person closest to their children to decide and convince where to study because they are the ones who will pay the tuition fees. Lee (2005) emphasized that decision makers have a strong tendency to consider both their cognitive and non-cognitive aspects, such as values and interests, in making decisions. Thus, solely relying on individuals' cognitive aspects may not provide a complete picture of their career decision making processes.

Brothers and sisters have also contributed to the decision of the respondents to choose maritime program while their relatives have little influence in making the decision in choosing the degree program and school. In the Philippines, most especially elder brothers and sisters, they also give their opinion regarding what is the best school and degree program for their siblings because sometimes they are helping the family to support financially the education of their younger siblings which is a good Filipino values and a good sign of gratitude. Aside from that, they are also being asked because parents are not knowledgeable enough about the in-demand professions nowadays and some of them maybe have not attended schools where they just have learned everything from experience.

Some students were also informally interviewed regarding their reasons of taking up Maritime program and some of them answered due to the frustrations of their father to become seafarers. Some of them have relatives working as officials and crews in shipping vessels and they were ensured that they could have immediate employment after graduation. Others have some apprehensions of not having accepted for shipboard training due to lack of connections.

Table 2 presents the factors that affect the choice of school among maritime students. They strongly agreed that one of the reasons of choosing the school is that LPU proven its ability to become home of board topnotchers and passers (3.52) and they also agreed that LPU has well known high quality standards (3.46). It is one of the best practices of the university to provide cash incentives for board top notchers in any degree program ranging from Php 60,000 to 100,000 depending on the positions landed in the top 10. LPU-Batangas already produced 249 board top notchers as of March 2015 and still counting.

Table 2. Factor affecting the choice of school

\begin{tabular}{llll}
\hline Quality Education: The University has... & WM & VI & Rank \\
\hline well known high quality standards & 3.46 & A & 2 \\
various certifications like ISO & 3.01 & A & 5 \\
tuition fee that compensates quality education & 3.28 & A & 4 \\
produced graduates who easily find jobs & 3.41 & A & 3 \\
proven its ability to become home of board topnotchers and passers & 3.52 & SA & 1 \\
\hline Composite Mean & 3.34 & A & \\
\hline Most of my friends/relative are enrolled in this school & 2.37 & D & 5 \\
\hline
\end{tabular}




\begin{tabular}{llll}
\hline Quality Education: The University has... & WM & VI & Rank \\
\hline Most of my classmates and close friends would like to study in LPU & 3.39 & A & 2 \\
My close relatives were Lyceum Alumni & 3.04 & A & 4 \\
Parent's Choice & 3.42 & A & 1 \\
High school teachers' advice & 3.27 & A & 3 \\
\hline Composite Mean & 3.09 & A & \\
\hline Personal Preferences & \multicolumn{3}{l}{} \\
\hline Own Choice & 3.57 & SA & 1 \\
Preferred course is offered & 3.41 & A & 2 \\
\hline Composite Mean & 3.49 & A \\
\hline Proximity and Accessibility & \multicolumn{3}{l}{} \\
\hline Near at our present family residence & 2.36 & D & 3 \\
This is the nearest university where maritime program is offered & 3.61 & SA & 1 \\
The transportation is accessible & 3.23 & A & 2 \\
\hline Composite Mean & 3.07 & A \\
\hline
\end{tabular}

It is part of the mission and vision of the institution to monitor the academic performance of its students to ensure that they possess the established student outcomes set for them to achieve before graduation. Nkang (2012) stressed that the qualifications of the university graduates must be internationally competitive through making realized the learning environment and students' outcomes thoroughly achieved.

Another reason is that the LPU graduates easily find jobs (3.41) and tuition fee compensates quality education (3.28). LPU or LIMA as ISO certified considered as their least reason of choosing the school. It seems that some parents were not much aware of the certifications but they will see the benefit of being ISO certified when they already experienced the services being provided to them as customer of the university.

The composite mean of 3.34 implies that the image of school in terms of providing quality education is highly considered by the students in choosing the school for their college education. Quality is being considered by anyone in making a decision. They chose LPU because they believe in the capability of this institution to provide quality education to its customers. Although managing quality in tertiary education in a multicultural population with different approaches according to Soomro and Ahmad (2012) is not only challenging and tough but also an uphill task, institutions must continuously be true to their mission of providing quality to its clients which can be recognized by the community as marketing tool for greater enrolment.

Parents (3.42) have always high regards in terms of choosing the school where their children will be trained as future professionals. The willingness of their High school classmates and friends to study in LPU (3.39) is also considered as factor that influenced their decision; advise from teachers in high school (3.27); and having close relatives who were LPU Alumni also contribute to their decision while having friends and relatives enrolled in LPU (2.37) is considered the least.

The Maritime students strongly agreed in choosing then university is their own choice (3.57) and they agreed that the preferred degree program is offered (3.41) in this university. This signifies that as early as high school, they know where to go in college. They believe in the capability of LPU to produce board passers and topnotchers. They know that they can get what they expect from the institution. In the study of Nadelson et al. (2013), they found out that personal reason is one of the students' perceived influences on the decisions of attending the University of their Choice.

The respondents strongly agreed that LPU is the nearest university where maritime program is offered (3.61) and the campus is accessible to transportation (3.23) while they disagreed that LPU is near their place or residence (2.36). Most of the maritime students were residents of Mindoro and other nearby provinces, therefore LPU is considered far from their residences. Instead of going to Manila and other international schools here and abroad, they prefer to enroll in provincial schools like LPU-Batangas because it can also provide the same quality of education that other prominent schools can offer. The cost of living in the province is less expensive compared to National Capital Region. Aside from that, the environment is also less polluted and populated in the province.

Table 3 shows the level of interest of maritime students towards their enrolled degree program. The students strongly agreed that maritime profession will take them for employment abroad (3.73) and it is their top priority(3.58). They are certain that the Maritime profession definitely will bring them to different places in the world since that is the true nature of their profession. They agreed that Maritime program is their personal choice (3.42) and they find it stimulating and challenging (3.42). They believe that they can manage the difficulties of 
some activities involved in maritime profession effectively (3.34). They also agreed that maritime is the field that they can do better (3.27) and they enjoy performing the skills and operations involved in maritime profession (3.18). Achievement of appropriate skills and knowledge can be best acquired from various school related factors such as effective implementation of curriculum with quality delivery of instruction through the aid of state-of-the-art facilities, well defined and employed student services, integration of values and strong involvement in research and community programs of the university (Dotong, 2014).

Table 3. Level of interest towards maritime program

\begin{tabular}{lccc}
\hline Interest Towards the Maritime Program & WM & VI & Rank \\
\hline Maritime is my top priority. & 3.58 & SA & 2 \\
Maritime is my personal choice & 3.42 & A & 3.5 \\
Maritime is the field that I think I can do better. & 3.27 & A & 6 \\
I enjoy performing the skills and operations involved in maritime field. & 3.18 & A & 7 \\
I believe that I can be successful along the maritime program. & 3.04 & A & 9 \\
I like the challenges that maritime program offers to me. & 3.15 & A & 8 \\
I believe that maritime profession will take me for employment abroad. & 3.73 & SA & 1 \\
I find maritime profession stimulating and challenging & 3.42 & A & 3.5 \\
I believe that I can manage the difficulties of some activities involved on maritime \\
program effectively & 3.34 & A & 5 \\
\hline Composite Mean & 3.35 & A & \\
\hline
\end{tabular}

Though they also agreed that they like the challenges that maritime program offers to them (3.15) and they can be successful along the maritime program (3.04) these obtained the least weighted mean scores. This signifies that they are still uncertain of what will happen after studying and finishing the program. There is still doubt on the back of their mind if maritime profession could really bring them to success.

The computed composite mean of 3.35 implies that the maritime students have high level of interest towards the maritime program. They were enrolled in a degree program where they are motivated to meet the difficulties of the maritime program no matter what happen. Learning to appreciate more the maritime program would bring them to more exciting experiences from the curricular and extracurricular activities prepared for them to hone as future mariners. Ramirez and Dizon (2014) emphasized the importance of identifying the interest towards the program wherein due to low level of interest, they would think sometimes to drop the enrolled uninteresting courses or even stop schooling.

Managing one's career is critical not only for those soon to be entering the labor market but, similarly, those starting to make the early stages of their college degree (Jackson, 2015). The role of the guidance counseling is therefore necessary to make the students learn to embrace and appreciate the nature of Maritime program. Students also depend on their teacher to develop more the interest (Yang, 2008) of the maritime students towards their enrolled degree program.

Table 4 reveals the differences on the factors that influence the choice of degree program and school and the interest towards the program between students from private and public schools. There is significant difference in the influence of people and interest towards the degree program as indicated by the p-values of 0.043 and 0.036 , respectively, which are less than the 0.05 level of significance. Thus, the null hypothesis is rejected on these variables. This signifies that maritime students from public schools have significantly higher chance of being influenced by people and they have significantly higher level of interest towards Maritime program compared to those students graduated from private.

Table 4. Differences between students' perceptions from private and public high schools on the factors affecting their choice of school and interest towards the maritime program

\begin{tabular}{lcccc}
\hline & Private & Public & p-value & Interpretation \\
\hline Quality Education & 3.39 & 3.28 & 0.281 & Not Significant \\
Influence of People & 2.86 & 3.32 & 0.043 & Significant \\
Personal Preference & 3.55 & 3.42 & 0.082 & Not Significant \\
Proximity and Accessibility & 3.15 & 2.98 & 0.169 & Not Significant \\
Interest towards the program & 3.21 & 3.49 & 0.036 & Significant \\
\hline
\end{tabular}


Meanwhile, the respondents do not significantly differ in terms of quality education, personal preference and proximity and accessibility as indicated by the $p$ - values which are greater than the 0.05 level of significance. Therefore, the no significant difference on these variables is accepted.

There is a tendency for Filipino family with economic income from average to below average to enroll their children in public schools to minimize the expenses of the family in sustaining the education of all children who went to school simultaneously. Parents of these children sometimes asked their relatives who have finished or just those have just reached college education regarding what degree program would be appropriate for their children who were also about to take college. The opinion of other people in choosing school and degree program is an important input to parents who have not attended formal schooling.

Students from average or below average family income or those students from public school have realized the need for them to hold on their dreams to live the life they are aspiring for establishing a good family. They saw primarily the kind of life of ordinary people from their classmates and friends who are living in below poverty level who really strive to survive.

Due to these findings, research on the comparison of character and values learned or acquired from private and public schools may be conducted to establish clear differences (if any) on the way private and public schools have influenced on shaping the personality and individuality of the students to be productive when they reach college and become responsible citizens of the country.

\section{Conclusion}

It is the personal choice of the students to enroll in maritime program in LPU-Batangas with the support primarily from their parents. The advice from brothers and sisters as well as teachers is also being considered in making their decision. Being home of board topnotchers and known for its standards are some of the qualities considered by the parents and students in choosing LPU. With the willingness of high school classmates and friends to enroll in LPU also contributes to their decision. Since LPU is one of the Maritime schools in the Southern part of Luzon in the Philippines, students from neighboring towns chose to enroll in LPU Batangas instead of going to Manila and other schools in the region or abroad.

They strongly believed that maritime profession will bring them to different parts of the world to fulfill their duties and responsibilities as seafarers. That is their number one motivation to pursue the maritime program. If they can practice the profession right after graduation and they have the eagerness to make their dreams come true, there is an assurance that they can come across all borders.

Students from public schools have significantly higher possibility of being influenced by their parents, siblings, friends and relatives; and they have significantly higher level of interest towards the degree program compared to students from private schools.

\section{Recommendation}

In the advent of K-12, no college freshmen will enroll starting School Year 2016-2017 in the Philippines, the university may offer Maritime education track for senior high school and encourage them to take this track in order for the university to use its facilities especially the laboratories and the faculty members may be provided teaching load during the first two school years of Senior High School of the K - 12 program which served as major change in the set up of collegiate schools in the Philippines. Parents may be invited during orientations to provide them deeper understanding of the demand in Maritime professions. Marketing efforts of the university may now focus among elementary schools to promote the junior and senior high school. Stachowski (2011) noted that educational marketing holds practical tools to help out higher educational institutions continue to exist and even flourish in such competitive and aggressive environments.

All the student achievements and university accomplishments may continuously be disseminated through various media like newspaper, television and radio commercials as well as tarpaulin printing and billboards as well as the use social networking media. Alumni achievements may also be announced in appropriate venue and occasion to honor them for what they have contributed for the community. They served as the living proof of what LPU have planted to grow personally and professionally.

Quality assurance mechanisms of the university like program accreditations, Investors in People, Philippine Quality Award, Autonomous Status and ISO certification may be explained in a language that parents and students as well as any ordinary people may understand the meaning of these initiatives and accomplishments for them. Nkang (2012) emphasized that the implementation of Quality Assurance Mechanisms will facilitate and help the university to the realization of their educational goals and objectives. The staff and faculty members of Lyceum International Maritime Academy may gather all maritime freshmen in a general assembly and discussed 
everything about the nature of the program of study and as a profession to get them motivated so that they can push their potential to the limits especially those students graduated from private schools. $\mathrm{Li}$ (2009) emphasized the importance of introductory class or the first or second week of meetings with the students where teachers have to provide them preliminary understanding on the twist and turns of the course and its relevance to the Maritime program itself, so that students will be inspired to learn and they will be more interested to finish the program. The changing expectations and perceptions of students for their experience in the university provide rationalization to continuously monitor the expectations of the students and their motivations for pursuing a college degree (Nadelson et al., 2013).

Understanding their duties and responsibilities will keep them aware of what to expect from the program and how they can achieve the specific program educational objectives as part of the implementation of Outcomes-Based Education. It would also help increase the students' level of interest towards the program especially those students who graduated from private schools if they are given enough time during class discussion to see the outside world of the profession through video presentation and actual scenarios of simulations and problem solving method. With that, they would responsive to the details on every aspect of the maritime program which would also trigger their motivation and attitude to keep well informed and educated of the profession.

This study was only limited to students enrolled in Maritime programs and it can also be conducted to other degree programs to confirm the result of the study. Other variables like marketing tools and strategies of the university may also be considered in future researches to measure its effectiveness and efficiency towards the attainment of target goals of the university in enrolment. The strength of the image of the university may also deem necessary to deeply assess as important factor that could also influence to the choice of school.

\section{References}

Akinyemi, G. M., \& Abiddin, N. Z. (2013). Quality Administration and Management in Higher Education in Nigeria: Implications for Human Resource Development. International Education Studies, 6(4), 225. http://dx.doi.org/10.5539/ies.v6n4p225

Bandura, A. (1986). Social Foundations of Thought and Action: a Social Cognitive Theory. Englewood Cliffs, NC: Prentice-Hall.

Costales, N. E. B. Jr., \& Zulueta, F. M. (2003). Methods of Research: Thesis-Writing and Applied Statistics (ch. 5, pp. 75-76). Navotas, Metro Manila, Philippines: Navotas Press.

Curran, J. M., \& Rosen, D. E. (2006). Student attitudes toward college courses: An examination of influences and intentions. Journal of Marketing Education, 28(2), 135-148. http://dx.doi.org/10.1177/0273475306 288401

Dotong, C. I. (2014). School-Related Factors in the Development of Graduates' Competencies towards Employability. Journal of Education and Literature, 2(1), 28-36.

Hirschi, A., \& Läge, D. (2008). Using Accuracy of Self-estimated Interest Type as a Sign of Career Choice Readiness in Career Assessment of Secondary Students. Journal of Career Assessment. http://dx.doi.org/10. $1177 / 1069072708317372$

Hirschi, A., \& Läge, D. (2007). The Relation of Secondary Students' Career-Choice Readiness to a Six-Phase Model of Career Decision Making. Journal of Career Development, 34(2), 164-191. http://dx.doi.org/10. 1177/0894845307307473

Hrnciar, M., \& Madzík, P. (2013). Improving the Quality of Higher Education in Central Europe: Approach Based on GAP Analysis. Higher Education Studies, 3(4), 75. http://dx.doi.org/10.5539/hes.v3n4p75

Jackson, D. (2015). Career Choice Status Among Undergraduates and the Influence of Work-Integrated Learning. Australian Journal of Career Development, 24(1), 3-14. http://dx.doi.org/10.1177/1038416215570043

Koni, A., Zainal, K., \& Ibrahim, M. (2012). An Assessment of the Services Quality of Palestine Higher Education. International Education Studies, 6(2), 33. http://dx.doi.org/10.5539/ies.v6n2p33

Laguador, J. M. (2014). Examination of Influence and Intention towards Lyceum of the Philippines University and Career Choice of General Engineering Students. International Journal of Management Sciences, 3(11), $847-855$

Lee, K. H. (2005). Coping with Career Indecision: Differences Between Four Career Choice Types. Journal of Career Development, 31(4), 279-289. http://dx.doi.org/10.1177/089484530503100405 
Lent, R. W., Brown, S. D., \& Hackett, G. (2002). Social Cognitive Career Theory. Career Choice and Development, 4, 255-311.

Nadelson, L. S., Semmelroth, C., Martinez, G., Featherstone, M., Fuhriman, C. A., \& Sell, A. (2013). Why Did They Come Here? The Influences and Expectations of First-Year Students' College Experience. Higher Education Studies. http://dx.doi.org/10.5539/hes.v3n1p50

Nkang, I. E. (2012). Challenges of Globalization and Quality Assurance in Nigerian University Education. International Education Studies, 6(1), 207. http://dx.doi.org/10.5539/ies.v6n1p207

Pafili, E., \& Mylonakis, J. (2011). Occupation Structure and Career Choice vs Education Development and Training Level: A Presentation of Theoretical Approaches. International Education Studies, 4(4), 22. http://dx.doi.org/10.5539/ies.v4n4p22

Ramirez, Y. P., \& Dizon, N. C. (2014). Assessment of Interest as Subjective Personal Data of Engineering Freshmen towards their Enrolled Degree Program. International Journal of Academic Research in Progressive Education and Development, 3(1), 195-207. http://dx.doi.org/10.6007/IJARPED/v3-i1/760

Soomro, T. R., \& Ahmad, R. (2012). Quality in Higher Education: United Arab Emirates Perspective. Higher Education Studies, 2(4), 148. http://dx.doi.org/10.5539/hes.v2n4p148

Stachowski, C. A. (2011). Educational Marketing: A Review and Implications for Supporting Practice in Tertiary Education. Educational Management Administration \& Leadership, 39(2), 186-204. http://dx.doi.org/10. 1177/1741143210390056

Stevan, F. (2014). Public Education Quality and Private School Enrollment (No. 2014_14). University of São Paulo (FEA-USP).

Vaz, A., \& Mansori, S. (2013). Malaysian private education quality: Application of SERVQUAL model. International Education Studies, 6(4), 164. http://dx.doi.org/10.5539/ies.v6n4p164

Yang, Y. (2008). The Importance of the Teacher for Developing Interest in Learning English by Chinese Students. International Education Studies, 1(1), 95. http://dx.doi.org/10.5539/ies.v1n1p95

\section{Copyrights}

Copyright for this article is retained by the author(s), with first publication rights granted to the journal.

This is an open-access article distributed under the terms and conditions of the Creative Commons Attribution license (http://creativecommons.org/licenses/by/3.0/). 